\title{
Groundwater sustainability assessment in coastal aquifers
}

\author{
U A Lathashri ${ }^{1, *}$ and A Mahesha ${ }^{2}$ \\ ${ }^{1}$ Department of Civil Engineering, Manipal Institute of Technology, Manipal, Udupi 576 104, India. \\ ${ }^{2}$ Department of Applied Mechanics 83 Hydraulics, National Institute of Technology Karnataka, \\ Surathkal, Mangalore 575 025, India. \\ ${ }^{*}$ Corresponding author. e-mail: ua.latha@gmail.com
}

The present work investigates the response of shallow, coastal unconfined aquifers to anticipated overdraft conditions and climate change effect using numerical simulation. The groundwater flow model MODFLOW and variable density groundwater model SEAWAT are used for this investigation. The transmissivity and specific yield estimated from the existing database range from 10 to $810 \mathrm{~m}^{2} /$ day and $0.08 \%$ to $10.92 \%$ respectively. After successful calibration with Nash-Sutcliffe efficiency greater than 0.80 , the values of horizontal hydraulic conductivity and specific yield of the unconfined aquifer were set in the range 1.85-61.90 m/day and 0.006-0.24 respectively. After validating the model, it is applied for forecasting the aquifer's response to anticipated future scenarios of groundwater draft, recharge rate and sea level rise. The findings of the study illustrate that saltwater intrusion is intensified in the area adjoining the tidal rivers, rather than that due to the sea alone. Of all the scenarios simulated, the immense negative impact on groundwater quality emerges due to overdraft conditions and reduced recharge with the areal extent of seawater intrusion exceeding about $67 \%$ (TDS $>1 \mathrm{~kg} / \mathrm{m}^{3}$ ). The study also arrives at the conclusion that, regional sea level rise of $1 \mathrm{~mm} /$ year has no impact on the groundwater dynamics of the aquifer.

\section{Introduction}

Groundwater in coastal regions is of major concern due to the fact that more than $60 \%$ of the world population lives within $30 \mathrm{~km}$ of shorelines and about 20\% (more than 205 million people) of the population of India lives in the coastal areas (INCCA 2010). Seawater intrusion is a major problem in many coastal aquifers. This occurs when the equilibrium between the seawater and freshwater is disturbed due to various reasons such as overdraft, land reclamation, climate changes, sea level rise, etc. A good understanding of the coastal dynamics and detailed knowledge of the variability of their parameters is essential to carry out studies on coastal aquifers (Carrera et al. 2010).
Modelling of coastal groundwater systems is a challenging problem due to their dynamic boundary conditions and the coupling between the equations for groundwater flow and solute transport (Post 2012). Hence, in the past few decades, solutions to these complex governing equations are sought using models such as SUTRA (Voss and Alden 1984), HST3D (Kipp 1986), SEAWAT (Guo and Bennett 1998) and MOCDENS3D (Essink 1999) that enable in-depth, three-dimensional modelling of freshwater-seawater interactions.

Complex processes such as aquifer and river system interaction and tidal influence on the coastal aquifers are well addressed with the use of MODFLOW (Chen and Hsu 2004; Babu et al. 2008; Post 2012). Also, a number of groundwater resource

Keywords. Coastal aquifer; seawater intrusion; SEAWAT; freshwater; solute transport; MODFLOW. 
management studies are carried out using MODFLOW (Ting et al. 1998; Ahmed and Umar 2009; El-Bihery 2009; Manghi et al. 2012; Camp et al. 2013) in recent years. Recently, the SEAWAT code is extensively used by researchers to explore both hypothetical and site specific cases involving sea water intrusion (Gates et al. 2002; Bauer et al. 2006; Qahman and Larabi et al. 2006; Lin et al 2009; Praveena et al. 2011; Cobaner et al. 2012; Chang and Clement 2013; Vandenbohede et al. 2014; El-Kadi et al. 2014) to assess the sustainable use of groundwater resources in the coastal aquifers and predict the freshwater-saltwater interface. Langevin (2003) presented the application of SEAWAT to estimate rates of submarine groundwater discharge to a coastal marine estuary. The SEAWAT model was used by Zhou et al. (2014) to simulate tide-induced groundwater flow and groundwater flow dynamics and the effect of beach slope on groundwater table in the unconfined aquifer of Donghai Island, China. The seasonal variation in natural recharge of coastal aquifers through two-dimensional hypothetical SEAWAT models was studied by Mollema and Antonellini (2013). They concluded that the continuous model is appropriate in simulating the quantity of freshwater in coastal aquifers for high rainfall regions. The studies on shallow fresh groundwater show that they are equally threatened by salinization (Giambastiani et al. 2007; Eeman et al. 2011; Vandenbohede et al. 2014) as are deeper freshwater resources. Most of the seawater intrusion studies are carried out to examine the impact of seawater intrusion in the deeper aquifers.

The average global sea level rise over the second half of the 20th century was $1.8 \pm 0.3 \mathrm{~mm} /$ year, and it would be likely of the order of $2-3 \mathrm{~mm} /$ year during the early 21st century as a consequence of global warming (IPCC 2008). Several attempts were made to study the effect of sea level rise on saltwater intrusion into coastal aquifer. Most of the studies conducted in coastal aquifers have concluded that groundwater extraction and decrease in recharge rates are predominant drivers of seawater intrusion when compared to sea level rise (Bobba 2002; Narayan et al. 2007; Loáiciga et al. 2012; Green and MacQuarrie 2014). Webb and Howard (2011) developed a series of hypothetical two-dimensional seawater intrusion models with SEAWAT in order to assess the impact of rising sea levels on the transient migration of saline intrusion in coastal aquifers under a range of hydrogeological parameter values. Rozell and Wong (2010) found in their study conducted on Shelter Island, New York that the effects of sea-level rise on the fresh water volume would be relatively minor. Feseker (2007) concluded from his studies that, rising sea level causes rapid progression of saltwater intrusion in coastal northwestern Germany, whereas the drainage network compensates changes in groundwater recharge. Comte et al. (2014) concluded from their studies on the coral island using the SEAWAT model that long-term changes in mean sea level and climatic conditions (rainfall and evapotranspiration) are responsible for an average increase in salinity.

The present study is taken up with the objective of understanding the response of an unconfined, shallow coastal aquifer to anticipated future stress and climate change scenarios under tropical climatic conditions. To achieve this objective, the most recent and effective numerical tool, SEAWAT, is used for simulating seawater-freshwater interaction in the study area.

\section{Description of the study area}

\subsection{Location, climate, rainfall and topography}

The study area is the aquifer system between the rivers Shambhavi and Pavanje located in the coastal Karnataka, India between $74^{\circ} 46^{\prime} 30^{\prime \prime}-$ $74^{\circ} 49^{\prime} 30^{\prime \prime} \mathrm{E}$ and $13^{\circ} 1^{\prime} 30^{\prime \prime}-13^{\circ} 6^{\prime} 00^{\prime \prime} \mathrm{N}$ (coloured area in figure 1) covering a spatial extent of about $26 \mathrm{~km}^{2}$ and a coastline of about $6 \mathrm{~km}$. The area is bound by the Arabian Sea on the west and the rivers Shambhavi and Pavanje along the northern and southern boundaries, respectively. The eastern boundary is marked with the ridge line with altitude up to about $60 \mathrm{~m}$. The river Pavanje flows from south to north along the coastline for a distance of about $500 \mathrm{~m}$ before its confluence with the river Shambhavi and then joins the Arabian Sea. The area has a population of about 30,860 which is expected to grow with a decennial growth rate of about $12.1 \%$ as per the 2011 population census of India.

The region is characterised by four seasons the monsoon (June-September), post-monsoon (October-November), winter (December-January), and pre-monsoon or summer (February-May) by the India Meteorological Department. The climate of the area is of the tropical humid type with moderate air temperatures of $36^{\circ} \mathrm{C}$ (May) and $21^{\circ} \mathrm{C}$ (December) during extreme seasons of the year and high levels of relative humidity ranging between $65 \%$ and $88 \%$. The average annual rainfall of the region is about $3500 \mathrm{~mm}$, with the greater part of about $85 \%$ occurring during the months of June through September due to the phenomenon of the southwest monsoon. This is evident from figure 2, where the monthly rainfall distribution at the National Institute of Technology, Karnataka, Surathkal, India is shown for the period beginning from January 1997 to December 2012. The ground surface elevation of the study area varies between 


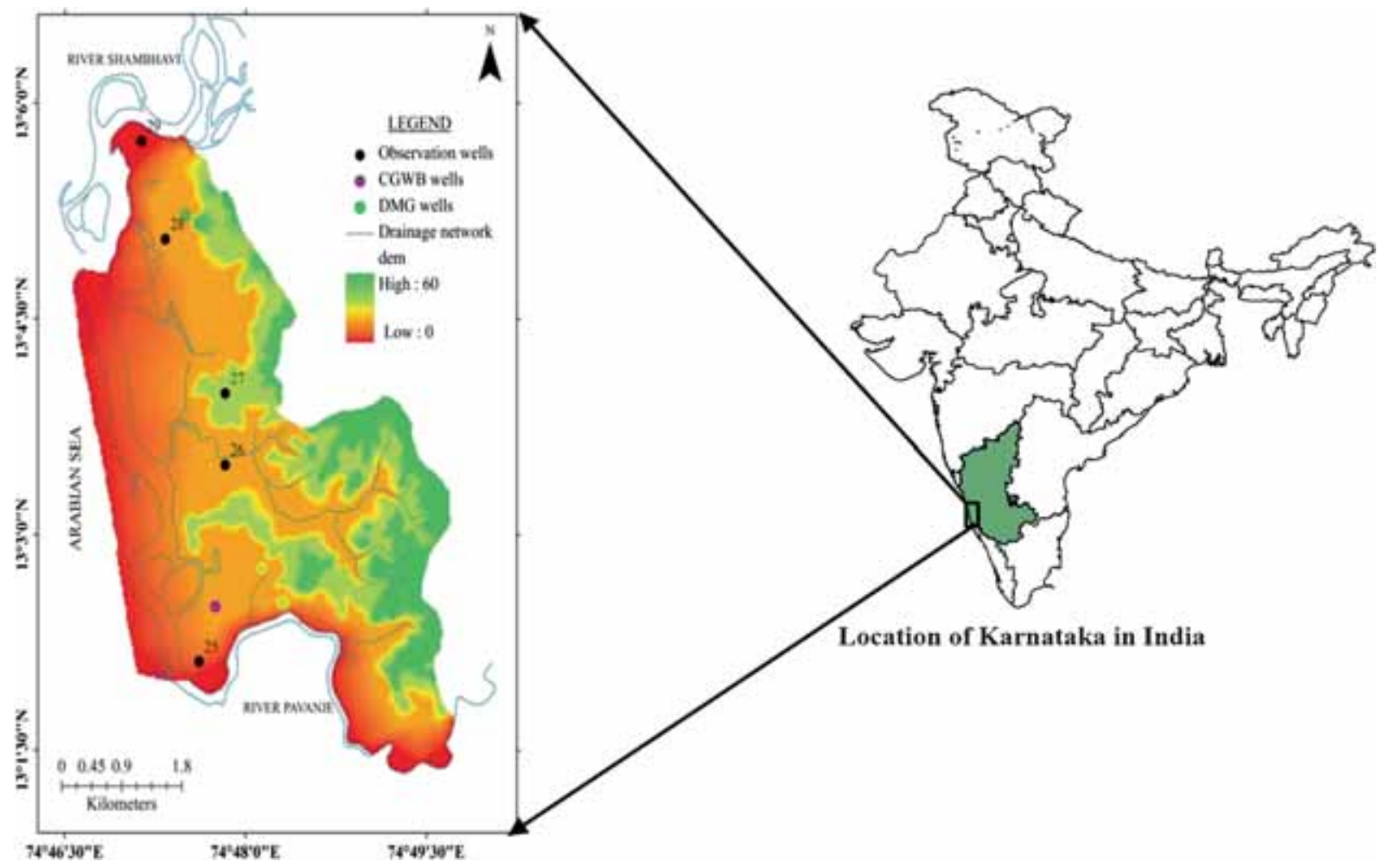

Figure 1. Study area map.

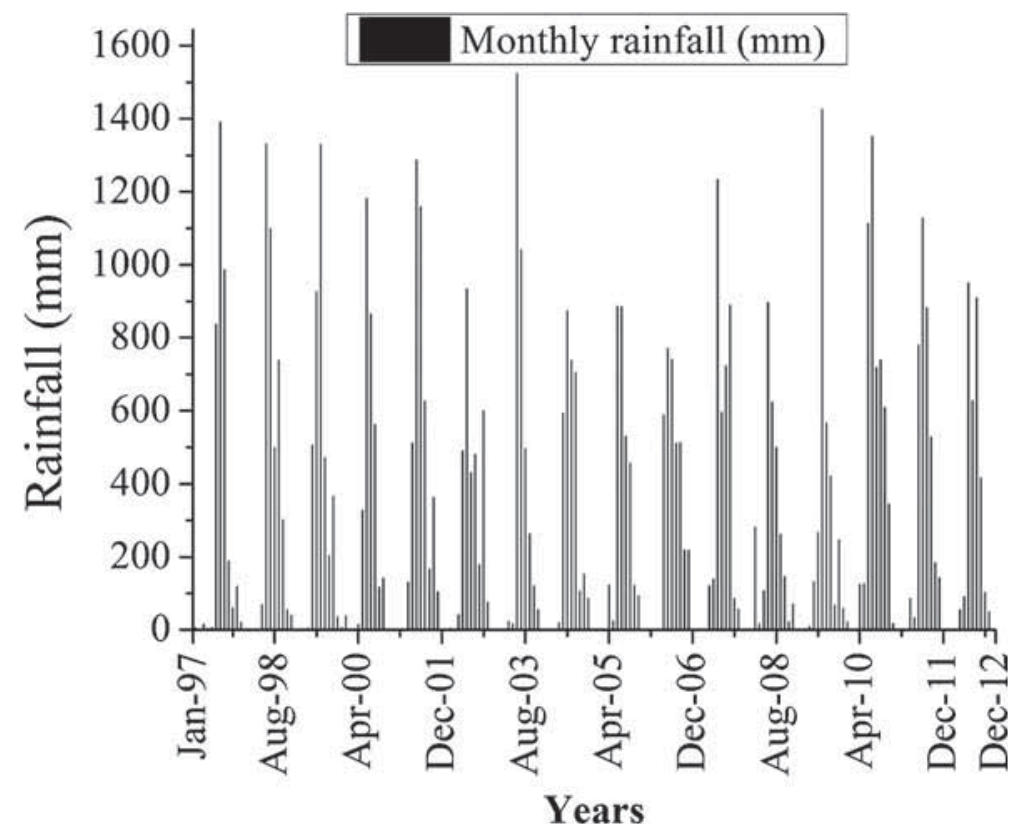

Figure 2. Histogram of monthly rainfallat NITK, Surathkal, India.

0 near the coast to $60 \mathrm{~m}$ AMSL (above mean sea level) towards the landward end.

\subsection{Soil}

The soil in the area is mainly of three types, namely (i) moderately deep, well drained, gravelly clay soils (ii) very deep, imperfectly drained, clayey soils, and (iii) very deep, well drained, gravelly clay soils with surface crusting and compaction as per NBSS and LUP (1998). Type (ii) soil is present in major portion of the coast. Further inland in the central region, type (iii) soil is located and type (i) soil is located in patches in the northern 
and southern areas. As far as the texture is concerned, the entire area falls under sandy loam texture (about $73 \%$ sand, $11 \%$ silt, $16 \%$ clay) except a small patch of land towards the north with sandy clay loam texture (about $66 \%$ sand, $6 \%$ silt, $28 \%$ clay).

\subsection{Geology}

The lateritic formation is underlaid by a thin bed of clay, granites, gneisses, and coastal alluvium along the coast. In the absence of bore log data pertaining to the area, the lithological unit map prepared by the KSRSAC (Karnataka State Remote Sensing Applications Centre), Bengaluru, is considered. As per the bore log data, an alluvial unit is present up to about $2 \mathrm{~km}$ from the coast. Also, the laterite unit covers a major portion of the area and a few patches of hard rock units are spotted at elevated terrains. A vertical electrical sounding survey is carried out (Honnanagoudar 2015) at one location in the area, and the results agree with the lithological unit map with a laterite unit which extends up to a depth of $20 \mathrm{~m} \mathrm{bgl}$. It is evident from the earlier investigations (Rao 1974; Srikantiah 1987) that the basin is predominantly an unconfined aquifer with depth ranging from 12 to $30 \mathrm{~m}$.

\subsection{Land use/land cover (LULC)}

The LULC data of scale 1:250000 derived from Resourcesat-1 satellite's Linear Imaging Selfscanning Sensor (LISS)-III data (2011-12) is downloaded from the Bhuvan-Thematic services website (http://bhuvannoeda.nrsc.gov.in/theme/ thematic/theme.php). This data consists of 19 classes which are then merged to get 5 required classes for the study area, namely built-up, agricultural, forest, barren/waste land and water bodies. According to the classification, $47 \%$ of the total area is covered by agricultural area and 35\% of forest land.

\section{Methodology}

\subsection{Numerical model}

A three-dimensional variable density model SEAWAT ver. 4 (Langevin et al. 2008) was used to resolve the spatio-temporal groundwater heads and salt concentrations in the basin. SEAWAT ver. 4 is a combination of well-known finite difference codes MODFLOW 2000 (Harbaugh et al. 2000) and MT3DMS 5.2 (Zheng and Wang 1999; Zheng 2006). MODFLOW is a constant density flow model and MT3DMS is a transport model. The coupling is necessary in order to account for the effects of density differences due to the mixing of high salt concentrations in seawater with freshwater in the coastal groundwater system. The steps involved in the present saltwater intrusion study are depicted in the form of a flowchart (figure 3).

\subsection{Model structure and hydrogeological parameters}

The model domain has a total of 2587 active cells and covers the total area, with each cell dimension being $100 \mathrm{~m} \times 100 \mathrm{~m}$. In the vertical direction, the domain extends down to $30 \mathrm{~m}$ below the mean sea level, representing the single layered unconfined aquifer unit. The contour lines of the toposheet no. $48 \mathrm{~K} / 16 / \mathrm{SW}($ scale $1: 25,000)$ at $10 \mathrm{~m}$ interval are digitised to generate digital elevation model (DEM) and is shown in figure 1. The raster DEM is imported and interpolated to the top elevation of the model grid. The details of the spatial discretization of model is as follows: $\mathrm{x}$-direction: 475,646E; y-direction: $1,439,602 \mathrm{~N}$ (with respect to origin of UTM WGS 1984, Zone 43), number of cells in xdirection: 65 ; y-direction: 95 . The daily time step is used for the simulation. The spatial and temporal discretizations were arrived at after initial stages of simulation based on the accuracy of the results.

The values of transmissivity and specific yield were obtained from pumping test analysis carried out at eight locations in the area by previous investigators (Ranganna et al. 1986; Harshendra 1991). The values of hydraulic conductivity and specific yield varied within this range during the calibration stage. A horizontal anisotropy of 1 was adopted for the model. Longitudinal dispersivity values ranging between 15 and $150 \mathrm{~m}$ were adopted during calibration as per Bhosale and Kumar (2001). A horizontal transverse dispersivity of $1 / 10$ th of the longitudinal dispersivity was assigned, as suggested by Cobaner et al. (2012). Molecular diffusion is an insensitive parameter and it can be ignored in the salinity calibration (Langevin et al. 2008). The concentration and density of seawater were defined as 35 and $1025 \mathrm{~kg} / \mathrm{m}^{3}$, respectively. Freshwater was considered as the reference fluid, with zero concentration and density equal to $1000 \mathrm{~kg} / \mathrm{m}^{3}$.

\subsection{Initial and boundary conditions}

The groundwater head obtained for a steady state model run for the month of October 2007 was used as the initial head for the transient groundwater flow simulation. The SEAWAT model, in fact, requires the concentration of total dissolved solids (TDS) which determines the density of the saline fluid, rather than the chloride concentrations. Hence, total dissolved solid (TDS) was used as an indicator of salinity (Qahman and Larabi 2006; Cobaner et al. 2012; Langevin and Zygnerski 2013) in the solute transport model. The measured 


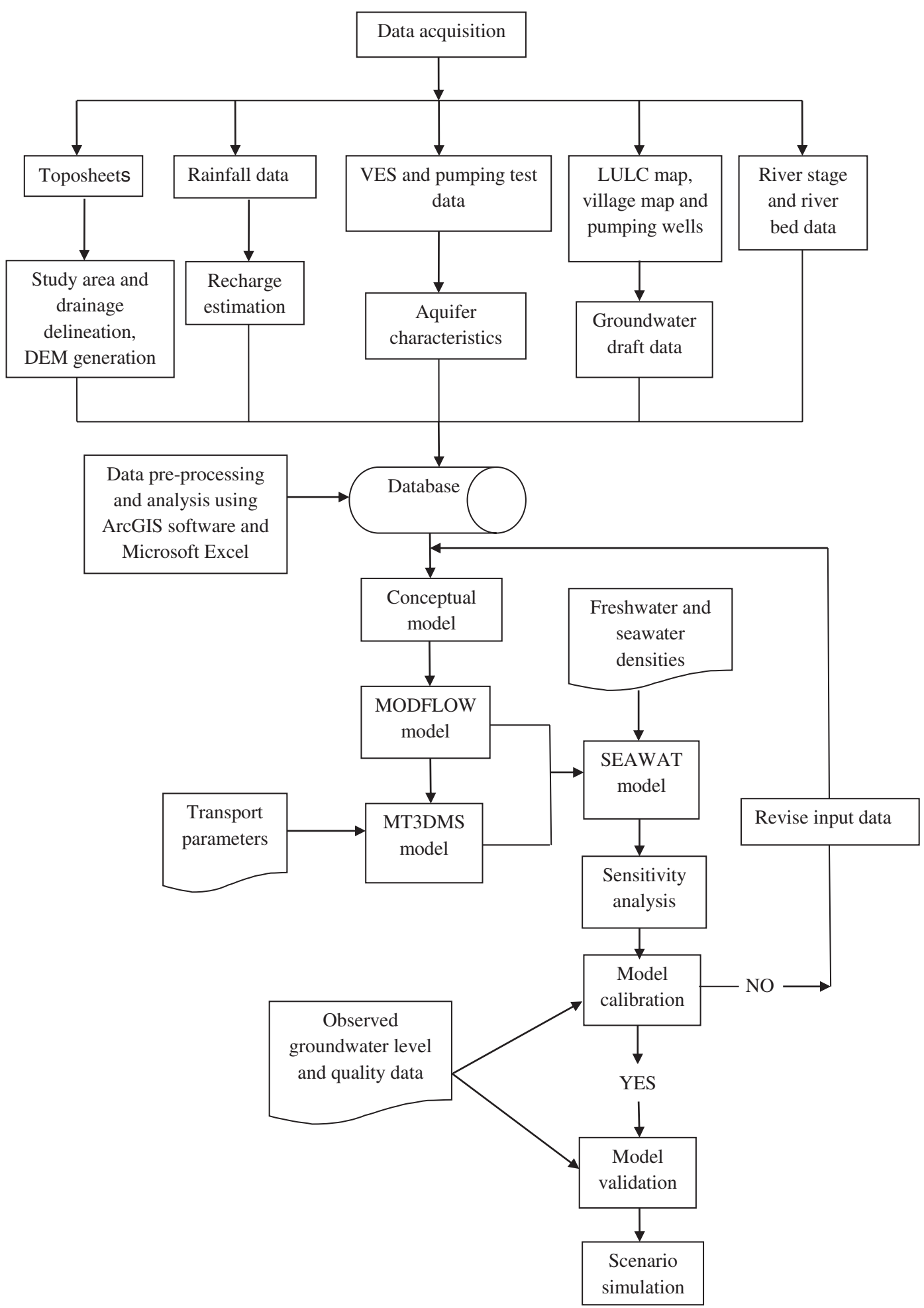

Figure 3. Flow chart for the methodology in the present study.

TDS during September 2011 was interpolated using Arc GIS 9.3, to obtain the TDS concentration for the entire study area and assigned as an initial concentration for the transport model.

\subsubsection{River package}

The rivers existing in the area are represented by arc features and were assigned as river boundary condition. The exact geometry and properties of a river channel cannot be represented in detail in a model grid (Rushton 2007). Hence, the riveraquifer interaction is represented by the river conductance and is incorporated node-wise in river package of MODFLOW. The river-bed elevation of $-2 \mathrm{~m}$ (with respect to mean sea level) was assigned to the node at the river mouth, as per 
Radheshyam (2010), and was gradually elevated away from the coast with a bed slope of 1 in 3000 . Accordingly, bed elevations of -1.63 and $0 \mathrm{~m}, \mathrm{msl}$, were assigned to the nodes of river Shambhavi and Pavanje, respectively, at their point of ingress into the study area. The monthly river stage data considered in the model were duly reduced as per the river-bed elevations. The widths of the rivers were measured using Google Earth which varies on an average of $80 \mathrm{~m}$ down south to $328 \mathrm{~m}$ along the coast and $296 \mathrm{~m}$ on the north. The river-bed thickness of $1 \mathrm{~m}$ was assumed. The river-bed conductivity was varied between a range of $2.5-12 \mathrm{~m} /$ day (Todd and Mays 2005) for fine and medium sand, as per field observation.

The rivers were assigned transient TDS values of $35 \mathrm{~kg} / \mathrm{m}^{3}$ during non-monsoon (October-May) months in order to account for the salinity carried by the backwater flow from the sea as per field observations. The rivers were considered as fresh (zero salinity) during the monsoon season (JuneSeptember). Apart from this, the boundary constituting the Arabian Sea (in the west) was assigned a constant head boundary with $0 \mathrm{~m}$ head and a constant TDS concentration of $35 \mathrm{~kg} / \mathrm{m}^{3}$. The eastern ridge line was assigned a no-flow boundary. The drain package was used to represent the drainage network (about $3 \mathrm{~m}$ wide and $1.5 \mathrm{~m}$ deep) that plays a vital role during the monsoon season (June to September) in discharging the surface run-off to the rivers flowing alongside. No flow cells were used on the eastern boundary to represent the no-flow boundary.

\subsection{Recharge and abstractions}

The rainfall during the monsoon season is a main source of replenishment to the aquifers. The Groundwater Estimation Committee of India (GEC 1997) recommends the recharge coefficient value as $7 \%$ for lateritic formations. Also, as per earlier work (Udayakumar 2008) in the area, the recharge coefficient values estimated to be between $8 \%$ and $26.5 \%$. The areally distributed recharge to the groundwater system is simulated using the recharge $(\mathrm{RCH})$ package.

The groundwater resource is extensively used for domestic and agricultural purposes in the vicinity of the area. As per the data possessed from Mangalore Electricity Supply Company Limited, 587 wells are located in the area with a total abstraction volume of $12,774 \mathrm{~m}^{3} /$ day, $10,950 \mathrm{~m}^{3}$ /day and $9122 \mathrm{~m}^{3}$ /day based on the water requirement of crops, i.e., evapotranspiration of 7, 6 and $5 \mathrm{~mm}$ /day during the pre-monsoon (February-May), monsoon (June-September) and post-monsoon (OctoberJanuary) periods, respectively as estimated by Kumar (2010). The wells which withdraw water from the aquifer at a specified rate during a given stress period are simulated using the well (WEL) package in MODFLOW.

The model domain exhibiting the MODFLOW and MT3MDS boundary conditions are displayed in figure 4 . The $\mathrm{X}$ and $\mathrm{Y}$ axes are represented by metres UTM (Universal Transverse Mercator) coordinate system. The MT3D boundary displays point source and sinks, the general definition of which are cells where certain conditions are set for

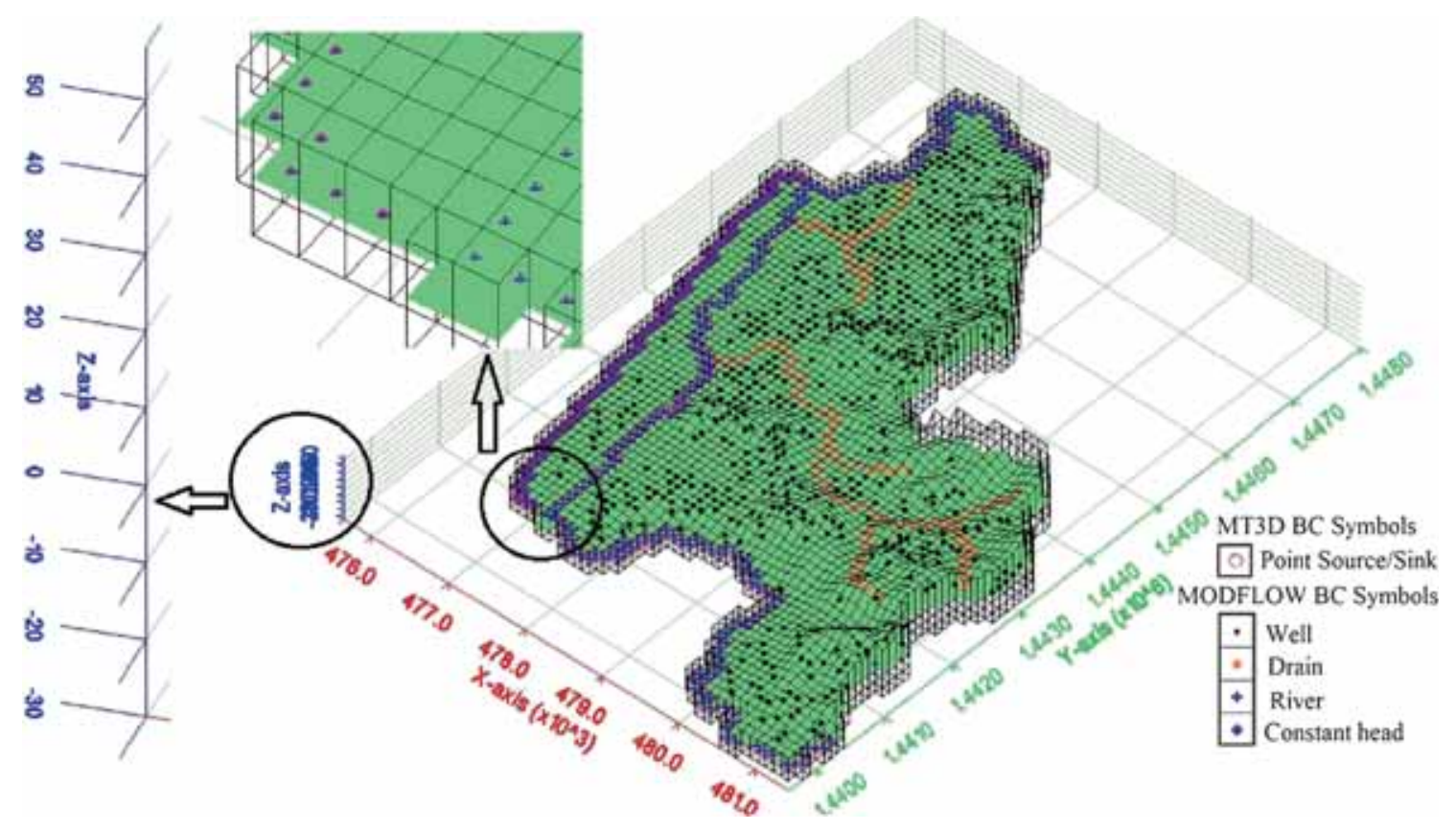

Figure 4. Model domain discretization. 
the inflow/outflow of water through the cell, which in the present case is the TDS concentration. An enlarged view of Z-axis and that of a section is shown which reveals the cells assigned with both flow and transport boundary conditions (river and the sea).

\subsection{Calibration and validation}

Initially, steady state calibration is carried out to choose the initial parameters. Then, the model was run in a transient mode for a 2-year period (2011-2013) with a daily time step, applying all the hydrogeologic conditions of the same period. In the present study, PEST version 12.2 (Doherty 2004) was used to calibrate the model. The model was then evaluated by comparing the simulated water table and TDS concentration with that of the observed (Honnanagoudar 2015).

It is important to check the authenticity of the model, before applying it for predictive scenario simulation; hence the validation run was carried out for an year period (2013-2014) subsequent to the calibration run. The model simulated water table is compared with that of the observed water table maintained by the Central Groundwater Board and the Department of Mines and Geology, Govt. of Karnataka.

Table 1. Zone-wise aquifer properties used after model calibration.

\begin{tabular}{lcc}
\hline Zone & $\begin{array}{c}\text { Hydraulic } \\
\text { conductivity }(\mathrm{m} / \text { day })\end{array}$ & $\begin{array}{c}\text { Specific } \\
\text { yield }\end{array}$ \\
\hline 1 & 2.12 & 0.006 \\
2 & 3.5 & 0.010 \\
3 & 5.01 & 0.012 \\
4 & 6.096 & 0.013 \\
5 & 9.656 & 0.029 \\
6 & 11.192 & 0.073 \\
7 & 14.89 & 0.095 \\
8 & 25.12 & 0.097 \\
9 & 32.18 & 0.105 \\
\hline
\end{tabular}

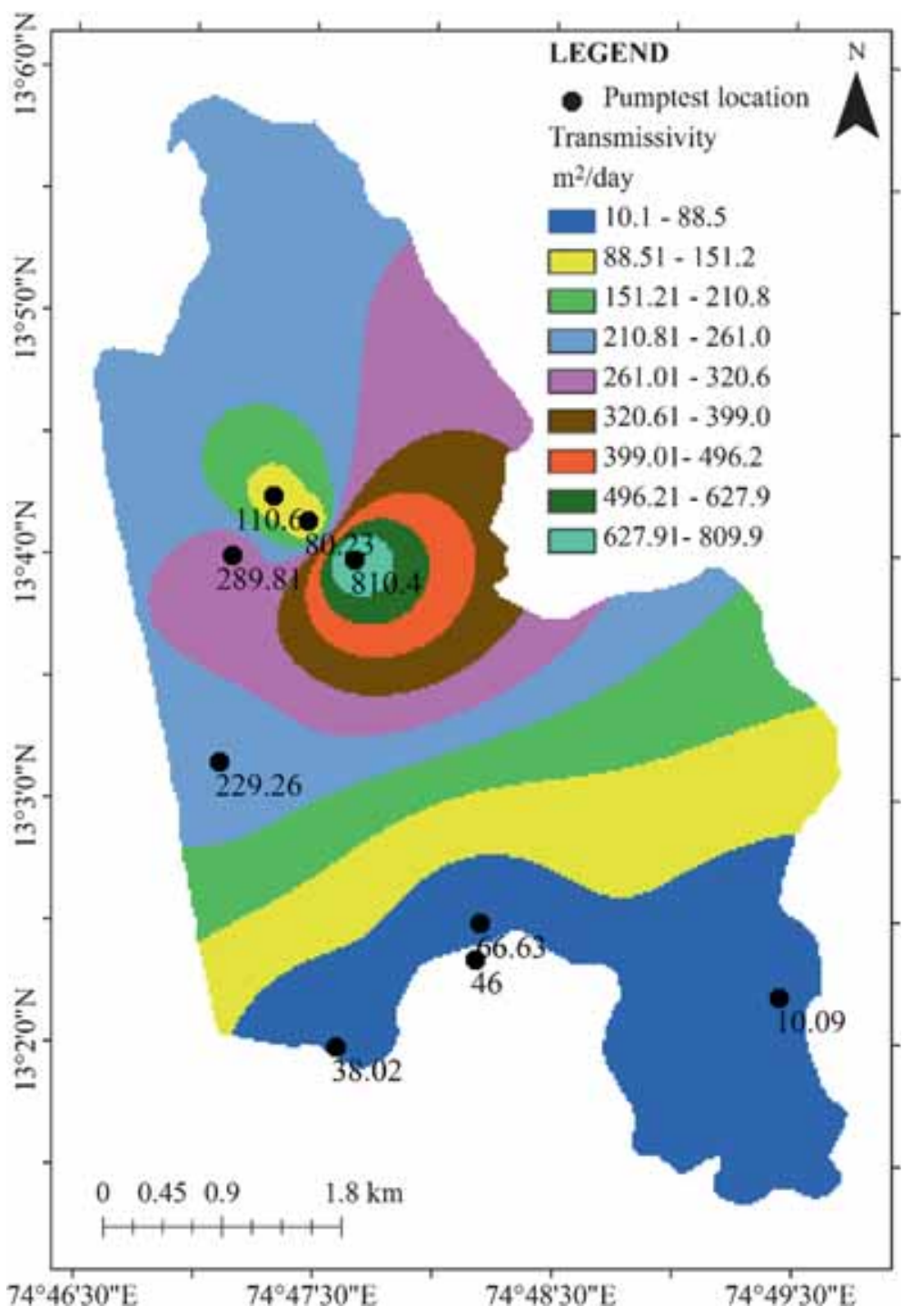

Figure 5. Transmissivity distribution map. 


\subsection{Scenario simulation}

The variations considered for recharge and abstraction are based on water demand for the next 20 years (2014-2034). As per the studies conducted (Unnikrishnan et al. 2006) on the Indian coast, a sea level rise of about $1-1.3 \mathrm{~mm} /$ year is estimated. Hence, the present study is intended to assess the response of the coastal aquifer under the following scenarios:

Scenario 1: Existing abstraction rate, calibrated recharge rate and no sea level rise.

Scenario 2: $50 \%$ decrease in recharge rate.

Scenario 3: $200 \%$ increase in abstraction rate.

Scenario 4: Scenario 2+ scenario 3.

Scenario 5: Scenario $4+1 \mathrm{~mm} /$ year sea level rise.

\section{Results and discussions}

\subsection{Model performance}

The values of statistical parameters obtained during steady state calibration as an indication of

Table 2. Groundwater flow model efficiency values on monthly basis during 2011-2013.

\begin{tabular}{lccc}
\hline \multicolumn{4}{c}{ Sub-basin 1} \\
\hline Month & $R^{2}$ & RMSE $(\mathrm{m})$ & NSE \\
\hline October & 0.967 & 0.700 & 0.927 \\
November & 0.953 & 1.047 & 0.823 \\
December & 0.985 & 1.001 & 0.852 \\
January & 0.988 & 0.904 & 0.865 \\
February & 0.973 & 0.911 & 0.876 \\
March & 0.976 & 1.025 & 0.834 \\
April & 0.988 & 0.998 & 0.845 \\
May & 0.972 & 1.005 & 0.816 \\
June & 0.544 & 2.447 & 0.077 \\
July & 0.867 & 1.097 & 0.865 \\
August & 0.935 & 1.110 & 0.830 \\
September & 0.771 & 1.440 & 0.755 \\
\hline
\end{tabular}

model performance are: coefficient of correlation $(r)=0.947$, coefficient of determination $\left(R^{2}\right)=$ 0.896 , root mean square error $(\mathrm{RMSE})=0.984 \mathrm{~m}$ and Nash-Sutcliffe efficiency (NSE) $=0.807$. The transmissivity values for the model are interpolated by inverse distance weighting (IDW) method to arrive at a spatial distribution map, based on which the area is categorised into nine zones (figure 5). The zone-wise calibrated aquifer parameters for the transient condition is presented in table 1 . The $R^{2}$, RMSE and NSE values for all months of the calibration period for the flow output are listed in table 2. The NSE is recommended for model evaluation by the ASCE (1993) which is most commonly used in hydrological applications. The NSE values between 0 and 1 are generally viewed as acceptable for model performance and values $\leq 0.0$ indicated unacceptable performance. During the calibration, the monthly NSE ranged from 0.816 to 0.927 except for the month of June. Zone 1 represents the low transmissivity zone and zone 9 represents the high transmissivity. The transmissivity and specific yield values range from 10 to $810 \mathrm{~m}^{2} /$ day and $0.08 \%$ to $10.92 \%$ respectively.

The simulated and observed water table and TDS are in good agreement with $R^{2}=0.87$ (figure $6 \mathrm{a}$ and $\mathrm{b}$ ). The observed and simulated water table for well nos. 26 and 28 are shown in figure 7 (a and b) with good agreement except for the month of June 2013 in well no. 28. After successful transient calibration, recharge coefficient of $20 \%$ of rainfall, a porosity of $30 \%$, riverbed conductance of $10 \mathrm{~m} /$ day and longitudinal dispersivity of $35 \mathrm{~m}$ are adopted. The estimated zone-wise hydraulic conductivity and specific yield used are listed in table 1 . The $R^{2}$, NSE and RMSE values obtained after analysing the observed and calibrated groundwater head at various observation points during validation are $0.749,0.608$ and $1.38 \mathrm{~m}$ respectively. However,
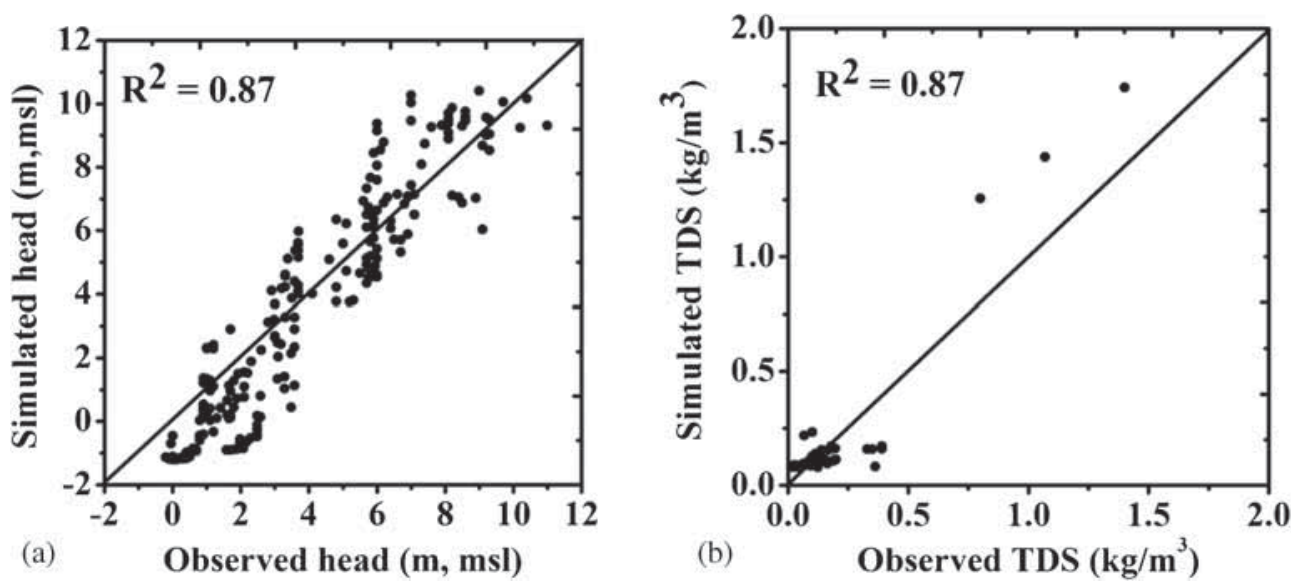

Figure 6. Scatter plot of observed and simulated (a) groundwater head and (b) TDS. 


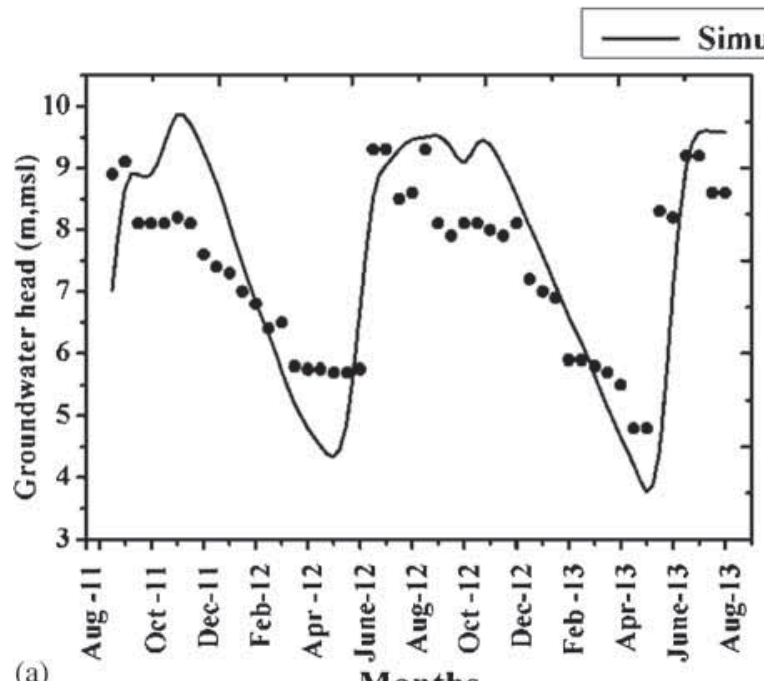

imulated

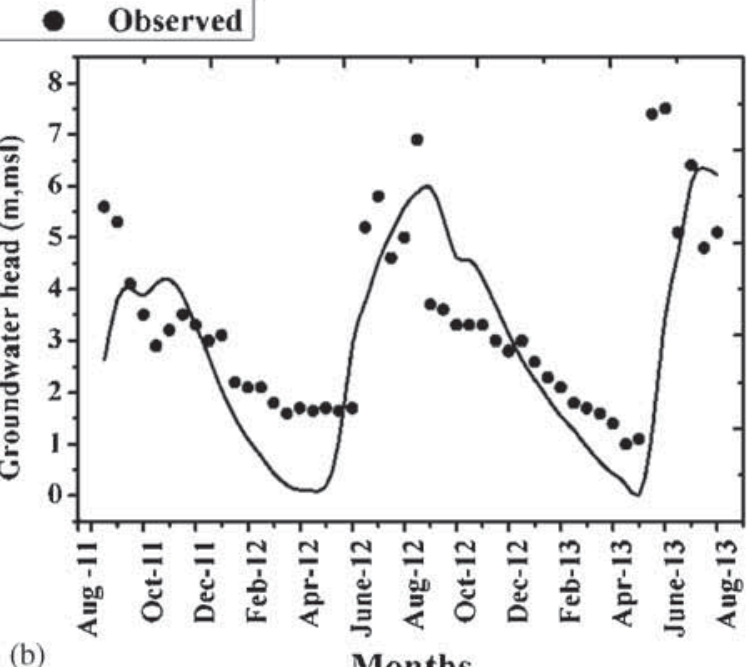

(b)

Months

Figure 7. Observed and simulated water table for (a) well 26 and (b) well 28 during the calibration (2011-2013).

Table 3. Volumetric water budget $\left(\mathrm{m}^{3} /\right.$ day) from MODFLOW.

\begin{tabular}{|c|c|c|c|c|}
\hline \multirow[b]{2}{*}{ Water balance components } & \multicolumn{2}{|c|}{ Monsoon } & \multicolumn{2}{|c|}{ Summer } \\
\hline & In & Out & In & Out \\
\hline Storage & 244.02 & 8521.25 & $10,288.75$ & 0.78 \\
\hline Constant head & 0.29 & 4841.11 & 1170.27 & 0 \\
\hline Wells & 0 & $10,950.28$ & 0 & $12,774.72$ \\
\hline Drains & 0 & $45,345.84$ & 0 & 0 \\
\hline River leakage & $4,204.71$ & $65,361.49$ & $10,621.87$ & 8965.88 \\
\hline Recharge & $130,521.98$ & 0 & 0 & 0 \\
\hline Total & $134,970.99$ & $135,019.97$ & $22,080.89$ & $21,741.37$ \\
\hline In - out & \multicolumn{2}{|c|}{48.98} & \multicolumn{2}{|c|}{339.53} \\
\hline$\%$ discrepancy & \multicolumn{2}{|c|}{0.04} & \multicolumn{2}{|c|}{1.55} \\
\hline
\end{tabular}

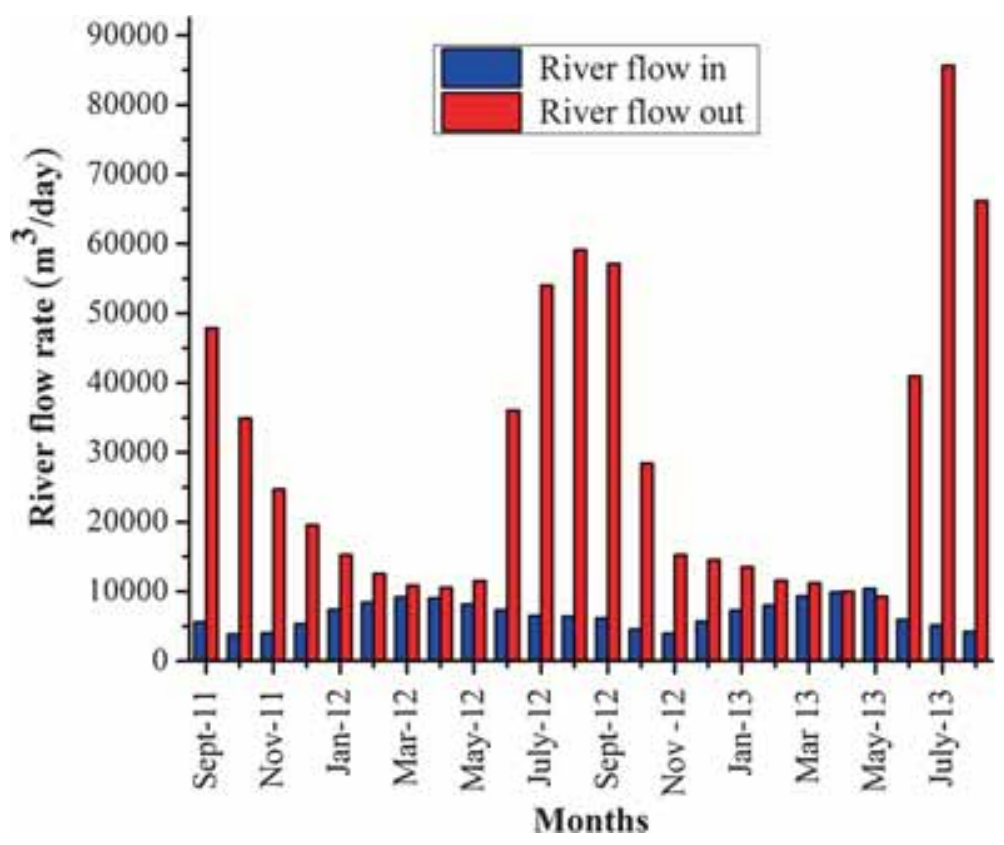

Figure 8. River flow rates from flow budget of MODFLOW during the calibration period (2011-2013). 
TDS concentration data was not available for the validation period.

\subsubsection{Water balance}

The groundwater mass balance simulation package, 'ZONEBUDGET' estimates the budget of volumetric flow rate of water in the whole system using the results from the MODFLOW. It uses cell-by-cell flow data in order to calculate the net inflows and outflows for a cell. The recharge, contribution from the rivers and sea, and storage due to aquifer properties form the inflow into the aquifer. The aquifer loses water due to pumping, discharge to the sea, river and drains. Table 3 presents the volumetric water budget during the monsoon and summer seasons. In both cases, the water movement into and out of the aquifer system can be considered dynamically stable, with the percentage discrepancy between the two being negligibly small.
Table 3 also indicates that the major input into the aquifer is through rainfall recharge. The major quantity of inflow into the aquifer is discharged into the sea/river during the wet season compared to that during the dry season throughout the coastline. During the dry periods, the volume of water flowing out of the aquifer along the coastline is much lesser than the flow into the aquifer indicating a higher probability of seawater intrusion. Since the rivers are tidal in nature, they contaminate aquifer system considerably during the non-monsoon months.

\subsubsection{Aquifer-river interaction}

The river-aquifer interaction plays an important role in sustainably managing water resources. In MODFLOW (McDonald and Harbaugh 1988), the river package simulates the effects of flow between surface water features and groundwater systems.
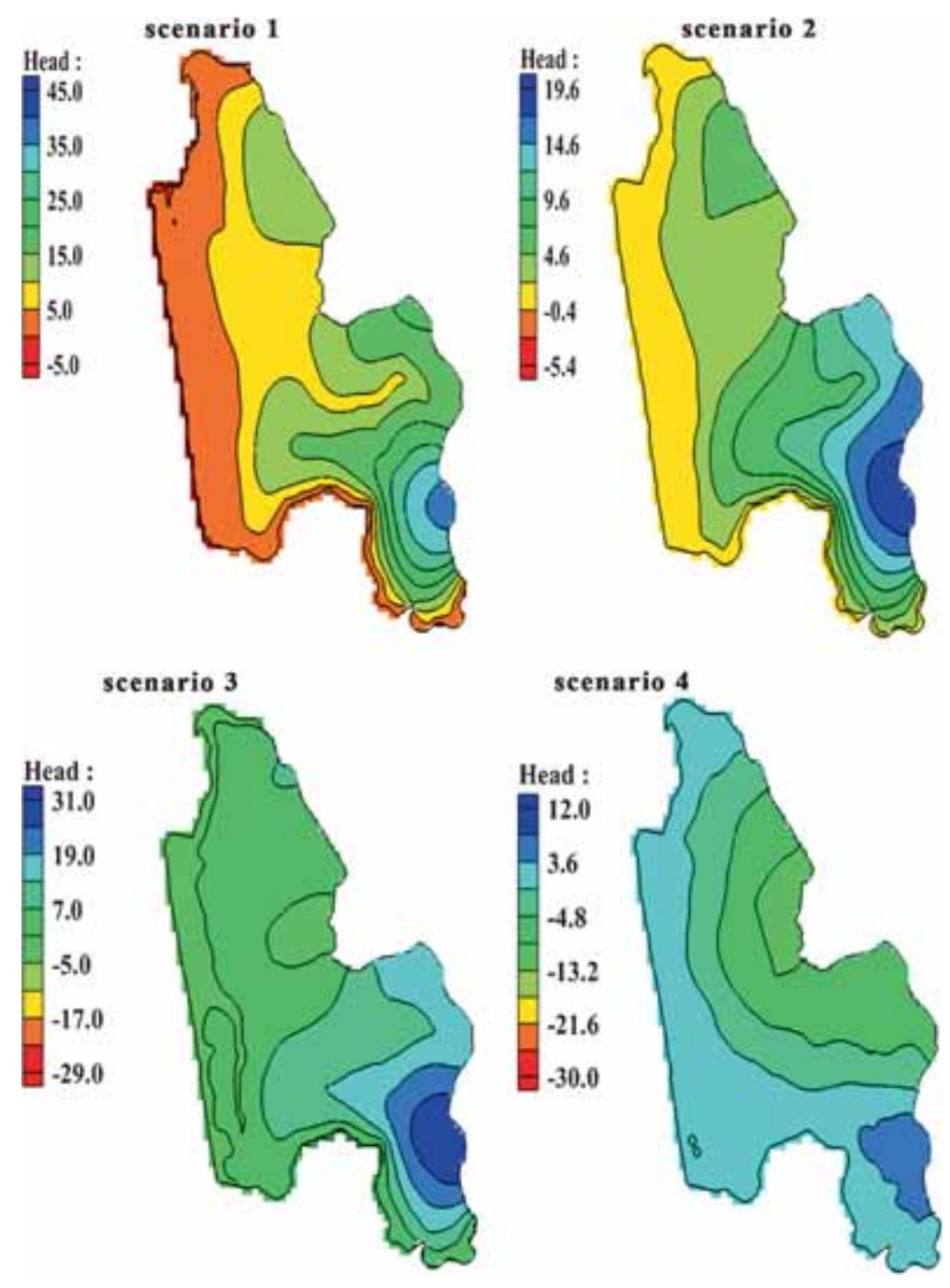

Figure 9. Estimated spatial distribution of water table for different scenarios at the end of 20 years (August 2034). 
The bar chart of river-aquifer interaction during the calibration period (2011-13) is presented in figure 8. The bar charts show a considerable amount of flow getting discharged out of the aquifer system into the sea. The flow rate out of the aquifer during June-September is up to $85,000 \mathrm{~m}^{3} /$ day compared to flow into the aquifer of $5000 \mathrm{~m}^{3} /$ day. This indicates that the recharged aquifer during the monsoon is draining into the sea without much deep percolation into the groundwater system. However, during the non-monsoon season, river inflow and outflow rates are almost equal to a figure of about $10,000 \mathrm{~m}^{3} /$ day. During this period, rivers carry saline water from the sea seeping into the adjoining aquifer.

\subsection{Spatial impacts of scenario simulation on the aquifer}

The calibrated model was used to predict the spatial and temporal impacts of all the five scenarios on the aquifer's vulnerability to saltwater intrusion for a 20 years period. The simulated heads and salinity distribution show significant spatial
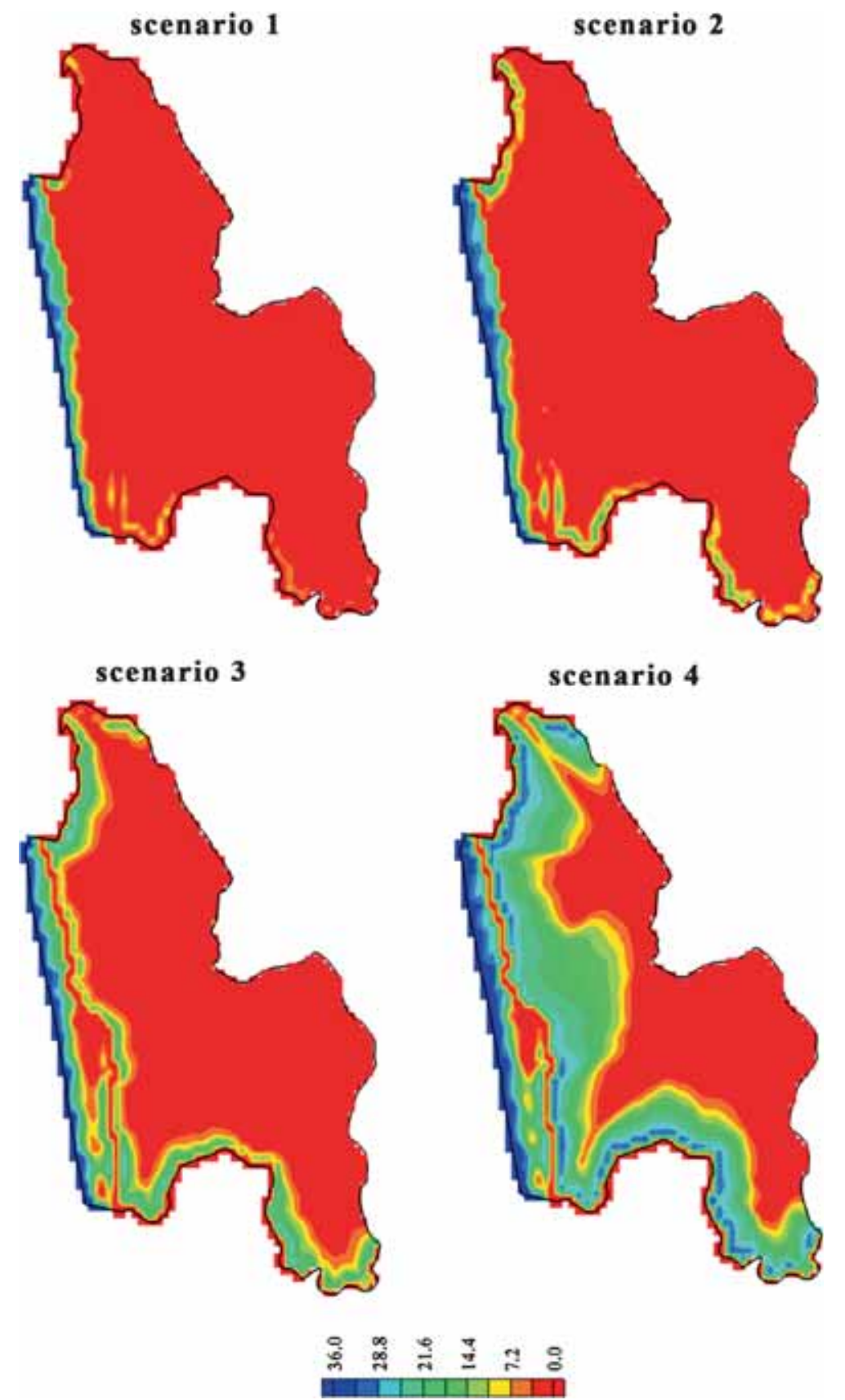

Figure 10. Estimated spatial distribution of salinity for different scenarios at the end of 20 years (August 2034). 
variability over the period (figures 9 and 10). The water table elevation decreases by an average $1 \mathrm{~m}$ in the case of scenario 2 whereas, it decreases by an average $3 \mathrm{~m}$ in scenario 3 . In the case of scenario 4 , the water table goes below mean sea level throughout the area which is not desirable. There was no difference in the end effect between scenario 4 and scenario 5 . The water table elevation and groundwater salinity at the observation wells for the scenarios considered are listed in table 4.

The upper limit of TDS for potable water is 1 $\mathrm{kg} / \mathrm{m}^{3}$ (World Health Organisation, WHO 2011). Similarly, the salt tolerance limits for the plants and vegetable range from $\mathrm{TDS}=3$ to $10 \mathrm{~kg} / \mathrm{m}^{3}$ (Comte et al. 2014). From the simulations, it was found that there is no considerable saltwater ingress into the midland areas (well nos. 26 and 27 ) for scenarios 1,2 and $3\left(\mathrm{TDS}<1 \mathrm{~kg} / \mathrm{m}^{3}\right)$. However, with increased freshwater draft (scenario 4 ), the TDS value increases to 16.30 and $11.80 \mathrm{~kg} / \mathrm{m}^{3}$ respectively. In the areas close to river Shambhavi (well nos. 28 and 29) water remains to be safe for potable use (TDS $<1 \mathrm{~kg} / \mathrm{m}^{3}$ ) up to scenario 2 . For other scenarios, water was found to be affected by salinity $\left(\mathrm{TDS}>3 \mathrm{~kg} / \mathrm{m}^{3}\right.$ ). In contrast to this, groundwater in the area close to river Pavanje as well to the sea (well no. 25), remains affected (TDS $>3 \mathrm{~kg} / \mathrm{m}^{3}$ ) by salinity in the beginning itself and the simulation for the scenarios aggravates the situation further (TDS up to $27.29 \mathrm{~kg} / \mathrm{m}^{3}$ ).

The sensitivity analysis is performed in the present study for the hydraulic conductivity, specific yield, recharge/pumpage and river-bed conductance. Out of these, the hydraulic conductivity, groundwater drafts were found to be affecting the seawater intrusion significantly. The water table elevation, groundwater salinity and percentage area affected by saltwater intrusion due to different anticipated scenarios are presented in table 4 . The saltwater intrusion is more sensitive to groundwater draft when compared to recharge rate in this region. This is evident from table 4 with the affected area significantly increasing for scenario 3 compared to scenario 1 . However, scenario 4 and 5 are considered to be the most unfavourable conditions, with the area of the aquifer available for drinking water (TDS $<1 \mathrm{~kg} / \mathrm{m}^{3}$ ) reducing to $32.20 \%$. Also, as concluded by many researchers, this study also shows a negligible effect of sea-level rise on groundwater with scenario 4 and 5 showing fairly similar results.

\subsection{Temporal impacts of scenario simulation on the aquifer}

The estimated water table elevations and groundwater salinity during the 20-year simulation for the scenarios considered are plotted at three key locations and are shown in figures $11-13$ and figures $14-16$, respectively. The decline in water table elevations for scenarios 3 and 4 are evident compared to scenarios 1 and 2. Due to the $50 \%$ decrease in recharge rate (scenario 2), the maximum water table elevation (during the wet period) falls by about $1 \mathrm{~m}$ whereas the minimum water table elevation (during dry period) coincides with that of scenario 1. This is because recharge due to rainfall is not applicable during the non-monsoon period. Interestingly, for scenario 2 , when the

Table 4. The water table elevation, groundwater salinity and percentage area affected by saltwater ingress due to different scenario simulations.

\begin{tabular}{|c|c|c|c|c|c|c|c|c|c|c|c|}
\hline \multirow{2}{*}{ Description } & & \multicolumn{2}{|c|}{ Scenario 1} & \multicolumn{2}{|c|}{ Scenario 2} & \multicolumn{2}{|c|}{ Scenario 3} & \multicolumn{2}{|c|}{ Scenario 4} & \multicolumn{2}{|c|}{ Scenario 5} \\
\hline & & $\begin{array}{l}\text { May' } \\
2034\end{array}$ & $\begin{array}{l}\text { Aug' } \\
2034\end{array}$ & $\begin{array}{l}\text { May' } \\
2034\end{array}$ & $\begin{array}{l}\text { Aug' } \\
2034\end{array}$ & $\begin{array}{l}\text { May' } \\
2034\end{array}$ & $\begin{array}{l}\text { Aug' } \\
2034\end{array}$ & $\begin{array}{l}\text { May' } \\
2034\end{array}$ & $\begin{array}{l}\text { Aug' } \\
2034\end{array}$ & $\begin{array}{l}\text { May' } \\
2034\end{array}$ & $\begin{array}{l}\text { Aug' } \\
2034\end{array}$ \\
\hline \multirow{5}{*}{$\begin{array}{l}\text { Resulting } \\
\text { water table } \\
\text { elevation } \\
(\mathrm{m} \mathrm{msl})\end{array}$} & Well no. 25 & -0.42 & 3.98 & -0.51 & 2.24 & -1.88 & 2.63 & -2.14 & 0.85 & -2.14 & 0.85 \\
\hline & Well no. 26 & 1.63 & 8.76 & -0.25 & 4.03 & -4.75 & 3.49 & -9.95 & -5.88 & -9.95 & -5.88 \\
\hline & Well no. 27 & 2.51 & 7.97 & 0.17 & 2.71 & -4.18 & 0.59 & -10.47 & -8.45 & -10.47 & -8.45 \\
\hline & Well no. 28 & -0.70 & 6.31 & -1.56 & 3.50 & -5.68 & 4.26 & -7.76 & -1.20 & -7.76 & -1.20 \\
\hline & Well no. 29 & -0.91 & 1.02 & -0.93 & 0.58 & -0.94 & 0.86 & -1.22 & 0.30 & -1.22 & 0.30 \\
\hline \multirow{5}{*}{$\begin{array}{l}\text { Resulting } \\
\text { groundwater } \\
\text { salinity } \\
\left(\mathrm{kg} / \mathrm{m}^{3}\right)\end{array}$} & 25 & 3.96 & 3.57 & 10.98 & 10.60 & 21.59 & 20.55 & 27.29 & 26 . & 27.29 & 26.75 \\
\hline & Well no. 26 & 0.03 & 0.03 & 0.05 & 0.05 & 0.02 & 0.02 & 16.30 & 16.04 & 16.30 & 16.04 \\
\hline & Well no. 27 & 0.03 & 0.03 & 0.04 & 0.04 & 0.02 & 0.02 & 11.80 & 11.74 & 11.80 & 11.74 \\
\hline & Well no. 28 & 0.04 & 0.04 & 0.06 & 0.06 & 3.01 & 2.93 & 22.82 & 22.39 & 22.82 & 22.39 \\
\hline & Well no. 29 & 0.45 & 0.40 & 0.44 & 0.43 & 3.88 & 3.27 & 12.46 & 11.73 & 12.46 & 11.73 \\
\hline \multirow{3}{*}{$\begin{array}{l}\text { Resulting percentage } \\
\text { area affected } \\
\text { by salinity }\end{array}$} & $\mathrm{TDS}<1 \mathrm{~kg} / \mathrm{m}^{3}$ & 78.62 & 86.86 & 74.72 & 82.64 & 60.80 & 68.49 & 32.20 & 39.43 & 32.20 & 39.43 \\
\hline & $\mathrm{TDS}<3 \mathrm{~kg} / \mathrm{m}^{3}$ & 81.87 & 89.87 & 78.39 & 86.16 & 65.98 & 74.06 & 37.03 & 44.34 & 37.03 & 44.34 \\
\hline & $\mathrm{TDS}<10 \mathrm{~kg} / \mathrm{m}^{3}$ & 85.70 & 93.74 & 82.53 & 90.38 & 74.37 & 82.18 & 46.93 & 54.46 & 46.93 & 54.46 \\
\hline
\end{tabular}


pumping rate is increased by $200 \%$, the maximum water table elevation coincides with that of scenario 2 (1 $\mathrm{m}$ decrease from scenario 1$)$, but the minimum water table elevation falls by about $1.5 \mathrm{~m}$. This indicates that the increased pumping rate during the wet period is compensated by recharge due to rainfall. However, in the case of scenario 4 , the maximum water table falls further by about $1.3 \mathrm{~m}$. Due to greater withdrawal and reduced recharge, the groundwater salinity increases sharply to TDS $>15 \mathrm{~kg} / \mathrm{m}^{3}$ within 4 to 5 years of operation for the cases 3 and 4 (figure 12).
However, it was found that the system reaches steady state by about 20 years. For the scenarios 1 and 2 , the salinity increase is much less compared to other cases but the attainment of steady state is slower as observed from figure 12 .

\subsection{Model limitations}

In the present work, the domain extends vertically down to $30 \mathrm{~m}$ below the mean sea level, representing the single layered unconfined aquifer based on the characterization of the aquifer reported

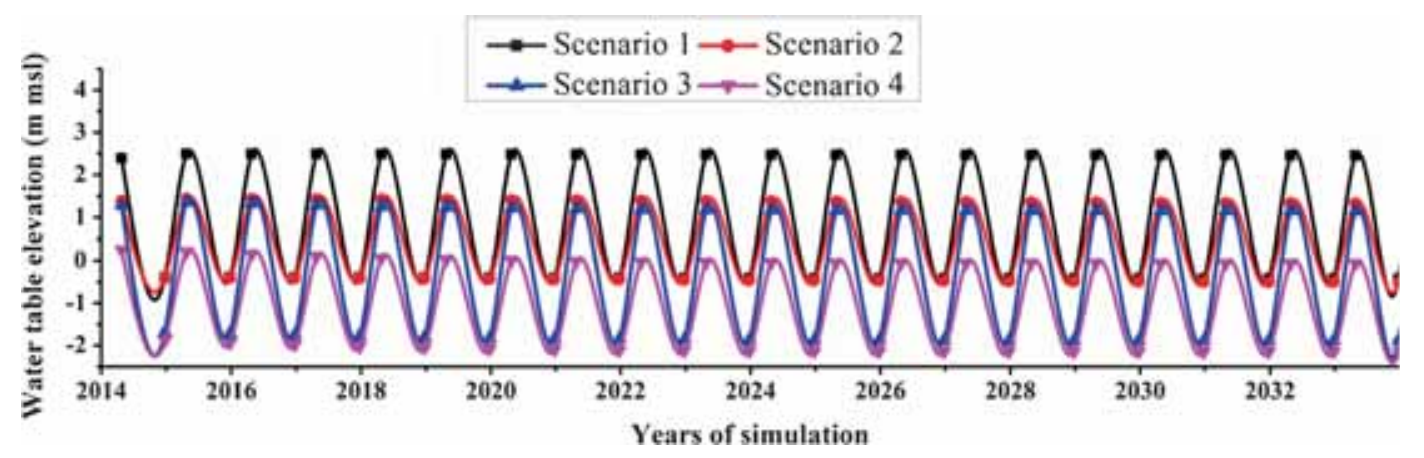

Figure 11. Variation of water table elevation over 20-year period near well no. 25.

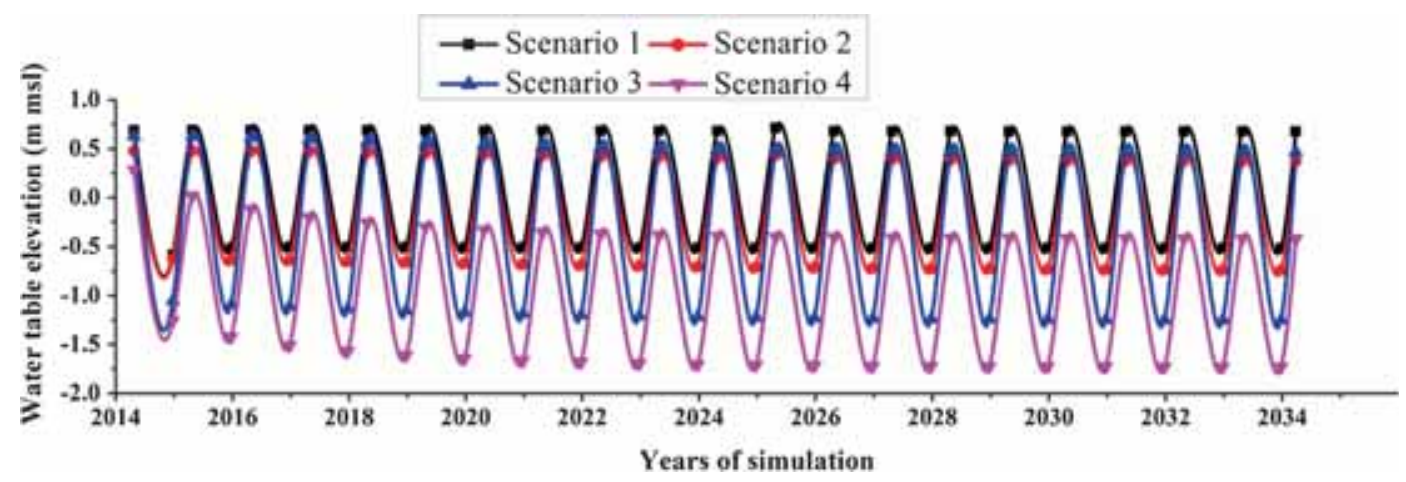

Figure 12. Variation of water table elevation over 20-year period at a grid $700 \mathrm{~m}$ from the coastline and $300 \mathrm{~m}$ from river Shambhavi.

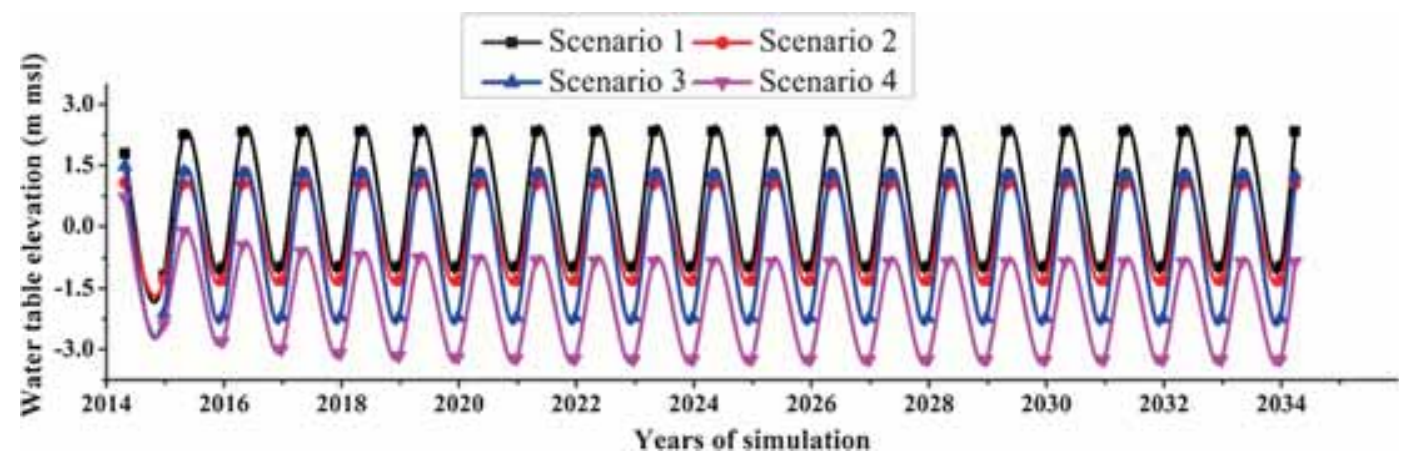

Figure 13. Variation of water table elevation over 20-year period at a grid $800 \mathrm{~m}$ from the coastline midway between river Shambhavi and river Pavanje. 


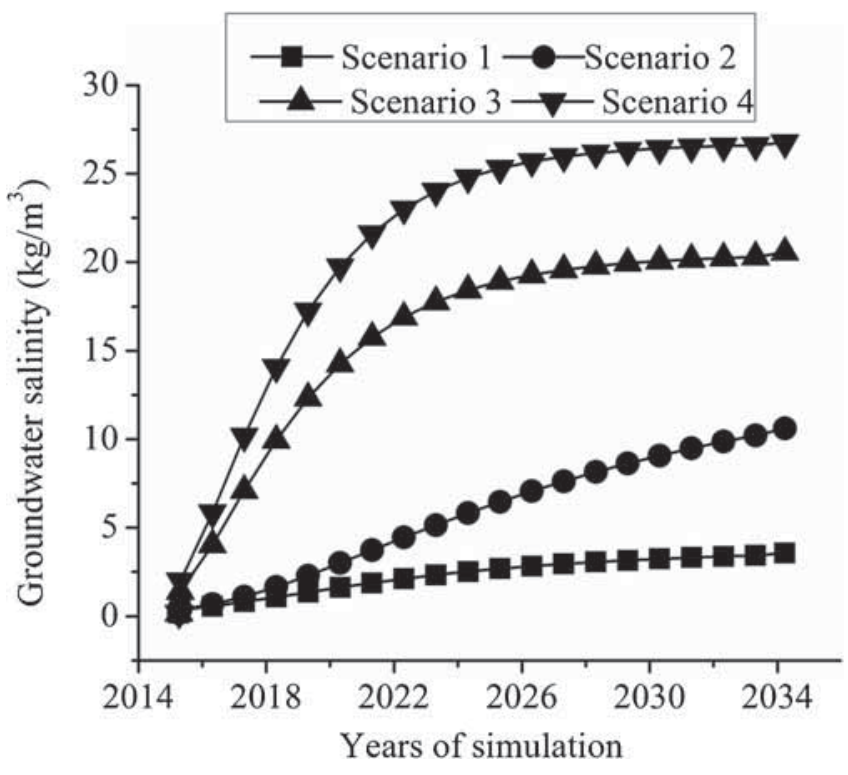

Figure 14. Variation of groundwater salinity over 20-year period near well no. 25.

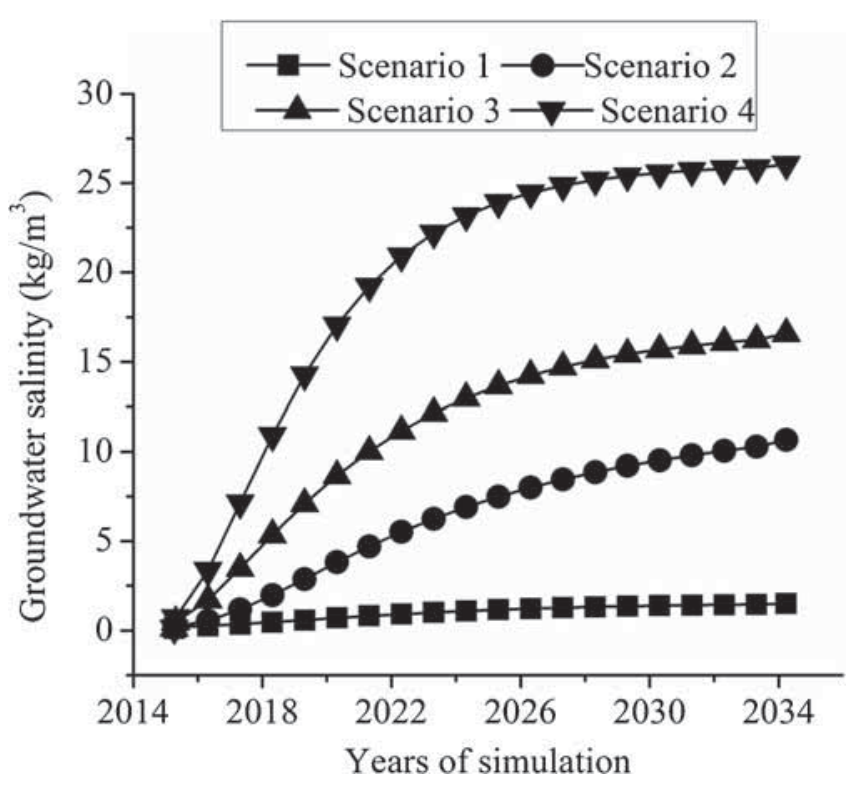

Figure 15. Variation of groundwater salinity over 20-year period at a grid $700 \mathrm{~m}$ from the coastline and $300 \mathrm{~m}$ from river Shambhavi.

earlier. The model performance during the monsoon (June-September) is not up to the mark, with all the three evaluation techniques showing deviation from the desired levels. The deviation between simulated and observed values may be because of the complexity of the substrata which is not accounted for by the model and is simulated as a single layered unconfined aquifer due to data scarcity. Also, there could be greater interaction/increased inflow of river water with seawater during these months, which is not well addressed

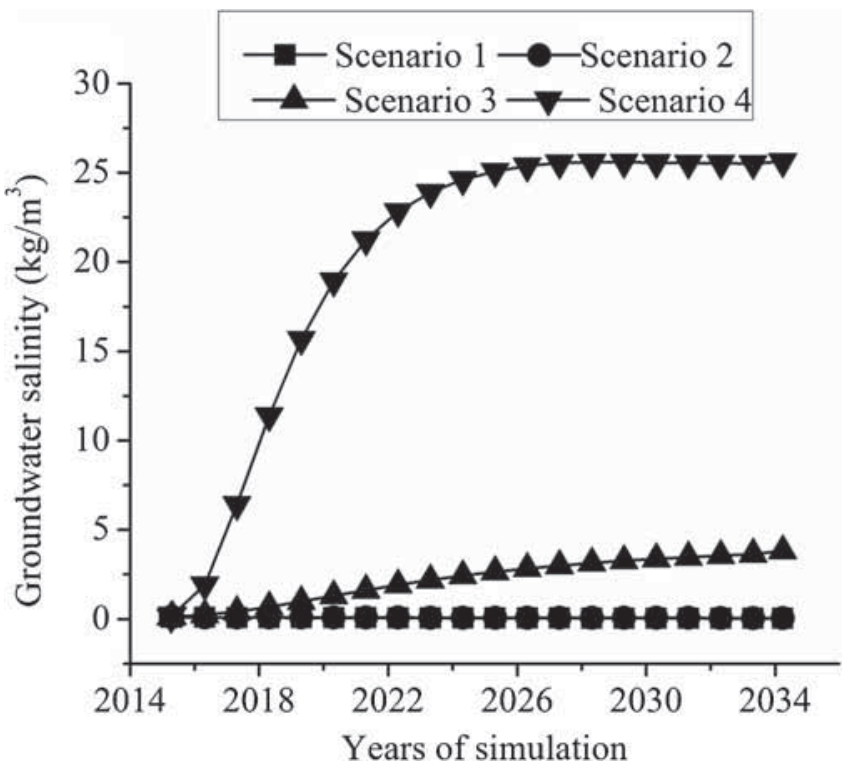

Figure 16. Variation of groundwater salinity over 20-year period at a grid $800 \mathrm{~m}$ from the coastline midway between river Shambhavi and river Pavanje.

by the model. The recharge considered in the model is during the period of monsoon (JuneSeptember). Any additional recharge due to early onset/delayed monsoon is not accounted in the model. The RMSE values are usually $\leq 1 \mathrm{~m}$, except that for the monsoon season. This is satisfactory for the kind of model developed with the execution of scarcely available input data in the most logical approach.

\section{Conclusions}

In the present study, an attempt was made to simulate the unconfined aquifer response to future anticipated scenarios arising out of increasing freshwater demand and climate change. The simulation was carried out using MODFLOW and SEAWAT. The basin was divided into 2587 elements having single layer over the depth with an element size of $100 \mathrm{~m} \times 100 \mathrm{~m}$. The aquifer parameters were selected based on earlier investigations which were subjected to transient calibrations. The basin was found to be having moderate groundwater potential with transmissivity and specific yield values of $10-810 \mathrm{~m}^{2} /$ day and $0.08 \%-10.92 \%$ respectively. The zone-wise aquifer parameters after calibration were used for the simulation. During the calibration, the performance of the model was found to be satisfactory with monthly Nash-Sutcliffe efficiency range of $0.816-0.927$. During the application of MODFLOW, the mass budget shows an egligible discrepancy between inflow and outflow ensuring the efficacy of the model. The model also estimates huge flow out of the aquifer into 
the sea/river during the monsoon highlighting the perviousness of the aquifer. The river-aquifer interaction indicates constant inflow into the system during January-May indicating a potential threat of saltwater contamination into the aquifers. The spatial and temporal variation of the water table and groundwater salinity were estimated for five future anticipated scenarios over a period of 20 years. The major criteria considered are increased freshwater draft, decreased recharge and sea level rise. From the results, it was evident that the freshwater draft was the most sensitive parameter causing saltwater intrusion. The scenario simulations indicate negative water table and total dissolved solids beyond the permissible limit with twice the freshwater draft from the present condition and half of present recharge. There was no effect of sea level rise of $1 \mathrm{~mm}$ on saltwater intrusion. The scenarios 3-5 resulted in increased salinity of 15 $\mathrm{kg} / \mathrm{m}^{3}$ within a period of 5 years of operation and attain steady state by 20 years. The simulation of present condition indicates that the salinity would be attaining a steady limit of $2 \mathrm{~kg} / \mathrm{m}^{3}$ over a period of 20 years. Thus, the outcome of the investigation gives an insight into the response of tropical, coastal aquifer to overdraft and climate change scenarios.

\section{References}

Ahmed I and Umar R 2009 Groundwater flow modelling of Yamuna-Krishni interstream, a part of central Ganga Plain, Uttar Pradesh; J. Earth Syst. Sci. 118(5) 507-523.

ASCE 1993 Criteria for evaluation of watershed models; J. Irrig. Drain. Eng. ASCE 119(3) 429-442.

Babu D S, Sahai A K, Noernberg M A and Marone E 2008 Hydraulic response of a tidally forced coastal aquifer, Pontal do Paraná, Brazil; Hydrogeol. J. 16(7) 1427-1439, doi: $10.1007 / \mathrm{s} 10040-008-0334-\mathrm{x}$.

Bauer P, Held R J, Zimmermann S, Linn and Kinzelbach W 2006 Coupled flow and salinity transport modelling in semi-arid environments: The Shashe River Valley, Botswana; J. Hydrol. 316(1) 163-183, doi: 10.1016/j.jhydrol.2005.04.018.

Bhosale D D and Kumar C P 2001 Simulation of seawater intrusion in Ernakulam coast, http://www.angelfire.com/ nh/cpkumar/publication/ernac.pdf.

Bobba A G 2002 Numerical modelling of salt-water intrusion due to human activities and sea-level change in the Godavari Delta, India; Hydrol. Sci. J. 47 S67-S80.

Camp M V, Mjemah I C, Al Farrah N and Walraevens K 2013 Modeling approaches and strategies for datascarce aquifers: Example of the Dar es Salaam aquifer in Tanzania; Hydrogeol. J. 21(2) 341-356.

Carrera J, Hidalgo J J, Slooten L J and Vázquez-Suñé E 2010 Computational and conceptual issues in the calibration of seawater intrusion models; Hydrogeol. J. 18(1) $131-145$.

Chang S W and Clement T P 2013 Laboratory and numerical investigation of transport processes occurring above and within a saltwater wedge; J. Contaminant. Hydrol. 147 14-24.

Chen B F and Hsu S M 2004 Numerical study of tidal effects on seawater intrusion in confined and unconfined aquifers by time-independent finite-difference method; J. Waterw. Port C. Ocean. Eng. ASCE 130(4) 191-206.

Cobaner M, Yurtal R, Dogan A and Motz L H 2012 Three dimensional simulation of seawater intrusion in coastal aquifers: A case study in the Goksu Deltaic Plain; J. Hydrol. 464-465 262-280.

Comte J C, Join J L, Banton O and Nicolini E 2014 Modelling the response of fresh groundwater to climate and vegetation changes in coral islands; Hydrogeol. J. 22(8) 1905-1920.

Doherty J 2004 PEST: Model-Independent Parameter Estimation; User Manual Water mark Numerical Computing, pp. $13-15$.

Eeman S, Leijnse A, Raats P A C and Van der Zee S E A T M 2011 Analysis of the thickness of a fresh water lens and of the transition zone between this lens and upwelling saline water; Adv. Water Resour. 34(2) 291-302.

El-Bihery M A 2009 Groundwater flow modeling of Quaternary aquifer RasSudr, Egypt; Environ. Geol. 58(5) 10951105.

El-Kadi A I, Tillery S, Whittier R B, Hagedorn B, Mair A, Ha K and Koh G W 2014 Assessing sustainability of groundwater resources on Jeju Island, South Korea, under climate change, drought, and increased usage; Hydrogeol. J. 22(3) 625-642.

Essink O G 1999 MOC3D adapted to simulate 3D densitydependent groundwater flow; In: Proceedings of the MODFLOW'98 Conference, pp. 291-303.

Feseker T 2007 Numerical studies on saltwater intrusion in a coastal aquifer in northwestern Germany; Hydrogeol. J. 15(2) 267-279.

GEC 1997 Groundwater Resource Estimation Methodology; Report of the Groundwater Resource Estimation Committee, Ministry of Water Resources, Government of India, New Delhi.

Gates T K, Burkhalter J P, Labadie J W, Valliant J C and Broner I 2002 Monitoring and modeling flow and salt transport in a salinity-threatened irrigated valley; $J$. Irrig. Drain. Eng. ASCE 128(2) 87-99.

Giambastiani M B, Antonellini M, Essink G H and Stuurman R J 2007 Saltwater intrusion in the unconfined coastal aquifer of Ravenna (Italy): A numerical model; J. Hydrol. 340 91-104.

Green N R and MacQuarrie K T B 2014 An evaluation of the relative importance of the effects of climate change and groundwater extraction on seawater intrusion in coastal aquifers in Atlantic Canada; Hydrogeol. J. 22(3) 609-623.

Guo W and Bennett G D 1998 Simulation of saline/fresh water flows using MODFLOW; Proceedings MODFLOW ' 98 Conference at the International Ground Water Modeling Center, Colorado School of Mines, Golden, Colorado.

Harbaugh A W, Banta E R, Hill M C and McDonald M G 2000 MODFLOW-2000, the U.S. Geological Survey Modular Ground-water Model - User guide to modularization concepts and the ground-water flow process; U.S. Geological Survey Open-File Report; 00-92.

Harshendra K 1991 Studies on water quality and soil fertility in relation to crop yield in selected river basins of Dakshina Kannada District of Karnataka State; Ph.D. Thesis, Mangalore University, Karnataka; India, 147p.

Honnanagoudar S A 2015 Studies on aquifer characterization and seawater intrusion vulnerability assessment of coastal Dakshina Kannada district, Karnataka; Ph.D. Thesis, National Institute of Technology Karnataka, Surathkal India, $184 \mathrm{p}$.

Indian Network for Climate Change Assessment 2010 Climate change and India: A $4 \times 4$ assessment sectoral and regional analysis for 2030s; Ministry of Environment \& Forests Government of India, http://www.moef.nic.in/ downloads/public-information/fin-rpt-incca.pdf. 
IPCC 2008 Intergovernmental Panel on Climate Change Technical Paper VI - Climate Change and Water, (eds) Bates B C, Kundzewicz S Wu and J P Palutik, 210p, http://www.ipcc.ch/pdf/technical-papers/climatechangewater-en.pdf.

Kipp Jr K L 1986 HST3D - A computer code for simulation of heat and solute transport in three dimensional groundwater flow systems; USGS Water Resources Investigations Report; 86-4095.

Kumar R B C 2010 Modelling regional actual evapotranspiration over Netravathi basin using satellite data; M.Tech Thesis, National Institute of Technology Karnataka, Surathkal, Mangalore, India, 30p.

Langevin C D 2003 Simulation of submarine ground water discharge to a marine estuary: Biscayne Bay, Florida; Ground Water 41 758-771.

Langevin C, Thorne D, Dausman A, Sukop M and Guo W 2008 SEAWAT version 4: A computer program for simulation of multi-species solute and heat transport; U.S. Geological Survey Techniques and Methods Book 6, Chapter A22.

Langevin C D and Zygnerski M 2013 Effect of sea-level rise on salt water intrusion near a coastal well field in southeastern Florida; Ground Water 51(5) 781-803.

Lin J, Snodsmith J B, Zheng C and Wu J 2009 A modeling study of seawater intrusion in Alabama Gulf Coast, USA; Environ. Geol. 57(1) 119-130.

Loáiciga H A, Pingel T J and Garcia E S 2012 Sea water intrusion by sea level rise: Scenarios for the 21st Century; Ground Water 50(1) 37-47.

McDonald M G and Harbaugh A W 1988 A modular three dimensional finite-difference groundwater flow model: USGS Open File Report USGS, Washington DC, pp. 83-875.

Manghi F, Williams D, Safely J and Hamdi M R 2012 Groundwater flow modeling of the Arlington basin to evaluate management strategies for expansion of the Arlington de-salter water production; Water Resour. Manag. 26(1) 21-41.

Mollema P N and Antonellini M 2013 Seasonal variation in natural recharge of coastal aquifers; Hydrogeol. J. 21(4) 787-797.

NBSS and LUP 1998 Soils of Karnataka for optimizing land use; National Bureau of Soil Survey and Land Use Planning, ICAR, Publication No, 47b, Nagpur, India, ISBN: 81-85460-45-0.

Narayan K A, Schleeberger C and Bristow K L 2007 Modelling seawater intrusion in the Burdekin Delta irrigation area, North Queensland, Australia; Agric. Water Manag. 89(3) 217-228, doi: 10.101b/j.agwat.2007.01.008.

Post V E A 2012 A new package for simulating periodic boundary conditions in MODFLOW and SEAWAT; Comput. Geosci. 37(11) 1843-1849.

Praveena S M, Abdullah M H, Aris A Z, Yik L C and Bidin K 2011 Numerical modelling of seawater intrusion in Manukan Island's aquifer; World Appl. Sci. J. 14 1-7.

Qahman K and Larabi A 2006 Evaluation and numerical modeling of seawater intrusion in the Gaza aquifer (Palestine); Hydrogeol. J. 14(5) 713-728.

Radheshyam B 2010 Study of coastal processes and solution to erosion problems in the vicinity of Netravathi-Gurupur river estuary - A modelling approach; Ph.D. thesis,
National Institute of Technology Karnataka, Surathkal, India, 223p.

Ranganna G, Gurappa K M, Gajendragad M R and Chandrakantha G 1986 Hazardous effects of groundwater pollution and mitigative measures there of; A Report by the Department of Applied Mechanics and Hydraulics, National Institute of Technology Karnataka, Surathkal India to the Department of Environment, Government of India, pp. 127-128.

Rao B N 1974 Geotechnical investigations of the marine deposits in the Mangalore harbor project; Indian Geotech. J. 4(1) 78-92.

Rozell D J and Wong T F 2010 Effects of climate change on groundwater resources at Shelter Island, New York State, USA; Hydrogeol. J. 18(7) 1657-1665.

Rushton K 2007 Representation in regional models of saturated river-aquifer interaction for gaining/losing rivers; J. Hydrol. 334(1) 262-281.

Srikantiah H R 1987 Laterite and lateritic soils of west coast of India; In: B. T. Proc. 9th South-east Asian Geotechnical Conference; Asian Institute of Technology, Bangkok, Thailand, pp. 159-169.

Ting C S, Zhou Y, De Vries J J and Simmers I 1998 Development of a preliminary ground water flow model for water resources management in the Pingtung Plain, Taiwan; Ground Water 36(1) 20-36.

Todd D K and Mays L W 2005 Groundwater hydrology; John Wiley and Sons, New York, 93p.

Udayakumar G 2008 Subsurface barrier for water conservation in lateritic formations; Ph.D. Thesis, National Institute of Technology Karnataka, Surathkal, India, pp. 53-69.

Unnikrishnan A S, Kumar K R, Fernandes S E, Michael G S and Patwardhan S K 2006 Sea level changes along the Indian coast: Observations and projections; Curr. Sci. 90(3) 362-368.

Vandenbohede A, Mollema P N, Greggio N and Antonellini M 2014 Seasonal dynamic of a shallow freshwater lens due to irrigation in the coastal plain of Ravenna, Italy; Hydrogeol. J. 22(4) 893-909.

Voss C I and Alden M P 1984 SUTRA; US Geological Survey Water Resources Investigation Reports.

Webb M D and Howard K W 2011 Modeling the transient response of saline intrusion to rising sea levels; Ground Water 49(4) 560-569.

World Health Organisation WHO 2011 Guidelines for drinking water quality, 4th edn, WHO, Geneva; 564. http://www.who.int/water_sanitation_health/publications/ 2011/dwq_guidelines/en/

Zheng C 2006 MT3DMS v5.2. Supplemental User's Guide; Department of Geological Sciences, University of Alabama.

Zheng C and Wang K 1999 A modular three dimensional multispecies transport model for simulation of advection, dispersion and chemical reactions of contaminants in groundwater systems; Contract Report SERD99-1, U.S. Army Corps of Engineers, United States.

Zhou P, Li G, Lu Y and Li M 2014 Numerical modeling of the effects of beach slope on water-table fluctuation in the unconfined aquifer of Donghai Island, China; Hydrogeol. J. 22(2) 383-396. 